\title{
1. INTRODUCTION: BREAKUP OF THE SOUTHEAST GREENLAND MARGIN AND THE FORMATION OF THE IRMINGER BASIN: BACKGROUND AND SCIENTIFIC OBJECTIVES ${ }^{1}$
}

\author{
Hans Christian Larsen, ${ }^{2}$ Andrew D. Saunders, ${ }^{3}$ Peter D. Clift, ${ }^{4}$ and the Shipboard Scientific Party ${ }^{5}$
}

\section{VOLCANIC AND NONVOLCANIC RIFTED MARGINS}

The structure and stratigraphy of rifted continental margins provide records of the rifting of continental lithosphere, the embryonic stages of the formation of the ocean lithosphere, the subsidence history of the margin, changes in relative sea levels of the adjacent ocean, and changes in paleoceanography and climate caused by plate kinematic movements or global changes. Consequently, studies of rifted margins have been given a high priority by the Ocean Drilling Program (ODP) and its predecessor, the Deep Sea Drilling Project (DSDP).

Traditionally, the evolution of rifted margins has been viewed as a process of repeated and progressively more intense continental rifting leading to breakup and initiation of seafloor spreading within highly thinned continental crust. Recent drilling on the margin off Iberia (ODP Legs 103 and 149) has shown that this type of margin development can indeed lead to strong thinning of the crust, including exposure of the deep crust and upper mantle.

During the 1980 s, however, increasing evidence for a different type of rifted margin associated with strong volcanism was provided by seismic imaging across several margins, in particular those in the North Atlantic (Hinz, 1981; Mutter et al., 1982; Smythe, 1983; Larsen, 1984). Deep multichannel seismic profiling revealed the presence of a characteristic stratigraphic architecture that consisted of seaward-dipping and offlapping reflectors of presumed volcanic origin, the so-called seaward-dipping reflector sequences (SDRS; Fig. 1). The SDRS, which can attain thicknesses of more than $6 \mathrm{~km}$ (Larsen and Jakobsdóttir, 1988), have since been discovered along the Mesozoic rifted margins of the Central and South Atlantic Ocean, and sections of the margins of Antarctica, Northwest India, and Northwest Australia (see review by Coffin and Eldholm, 1992). Hence, margin segments marked by voluminous volcanism seem to be as common as, or even more common than, margin segments that are characterized by strong tectonic thinning and low volcanic productivity.

Geophysical observations of the upper crust were substantiated by DSDP Leg 81 (Rockall Margin) and ODP Leg 104 (Vøring Margin). These cruises showed that the SDRS structure was composed predominantly of basaltic lavas that erupted in a subaerial or shallow-water environment. Wide-angle seismic experiments have proven that the SDRS are underlain by an approximately 20 -km-thick crust having a high-velocity lower layer (7.1-7.5 km/s; White et al., 1987, 1992; Holbrook and Kelemen, 1993). An igneous, "underplated," origin was proposed by White et al. (1987) for the high-velocity part of this thick, transitional lower crust within the continent/ocean transition.

These findings differ fundamentally from the conventional image of rifted margins in three principal aspects: (1) breakup and early sea-

\footnotetext{
' Larsen, H.C., Saunders, A.D., Clift, P.D., et al., 1994. Proc. ODP, Init. Repts., 152: College Station, TX (Ocean Drilling Program).

${ }^{2}$ Danish Lithosphere Centre, Geological Survey of Greenland, Øster Voldgade 10. DK-1350, København, Denmark.

${ }^{3}$ University of Leicester, University Road, Leicester LE1 7RH, United Kingdom.

${ }^{4}$ Ocean Drilling Program, Texas A\&M University, 1000 Discovery Drive, College Station, TX 77845, U.S.A

${ }^{5}$ Shipboard Scientific Party is as given in list of participants preceding the contents.
}

floor spreading took place near sea level, as opposed to the 2.5- to 3-km-deep water environment envisaged for the highly thinned continental crust; (2) formation of the excessively thick igneous crust formed by the SDRS and the underlying underplated material required anomalously high mantle temperatures; and (3) the actual breakup appears to represent a discrete geological event; a relationship to earlier continental rifting may be limited or even absent. Moreover, some of Earth's continental flood basalt provinces, such as the South American Paraná, southern African Karoo, and the North Atlantic Tertiary Volcanic Provinces, are associated with volcanic rifted margins and are approximately coeval with breakup (Cox, 1989; White and McKenzie, 1989; Peate et al., 1990; Coffin and Eldholm, 1992). Together with the newly discovered offshore SDRS provinces, they form the largest igneous provinces (LIPs) on Earth.

Differences between the two types of rifted margins have led to an informal classification into nonvolcanic and volcanic rifted margins. A typical volcanic margin structure is shown in Figure 1. The excess volcanism of these margins commonly is related to hot mantle plumes (e.g., Hinz, 1981; Vink, 1984; White et al., 1987; Larsen and Jakobsdottir, 1988; White, 1988; McKenzie and Bickle, 1988; White and McKenzie, 1989); however, the process is as yet poorly constrained by pertinent observational data.

In the years 1988 to 1990 , ODP received a number of proposals to investigate the nature of these two different types of margins. A North Atlantic Rifted Margin Detailed Planning Group (NARM-DPG) reviewed proposals and provided an integrated, multileg plan for rifted margin studies (Larsen, Sawyer, et al., 1991). Leg 152 is the second of these cruises and the first to address volcanic rifted margins.

The Northeast Atlantic was chosen by NARM-DPG as the optimum location for conducting studies of volcanic rifted margins, because (1) well-developed and seismically well-imaged SDRS occur along sediment-starved margins and allow for deep basement penetration; (2) the SDRS can be spatially and stratigraphically related to well-studied continental basalt provinces, such as East Greenland, the northwestern British Isles, and the Faeroes; (3) the region has been studied previously by deep-sea drilling and thus an extensive database already exists; and (4) it is an appropriate region to test the hypothesis that the excess thermal energy present during breakup was supplied by a mantle plume (i.e., the ancestral Iceland hotspot).

The main strategy of the NARM-DPG was to create three different drilling transects, each of which could establish the development of volcanism with time and could jointly provide a spatial image of volcanism. Spatial variations in volcanism as a function of distance from the Iceland hotspot, and possibly also as a function of lithospheric setting, were to be expected (Figs. 2, 3, and discussion below). Among these, the EG63-transect (East Greenland, $63^{\circ} \mathrm{N}$ ) had the highest priority. Leg 152 was scheduled to drill two deep holes along this transect, and two or more holes were planned for future drilling.

In the following sections, we review the general physiography and formation of the Northeast Atlantic Ocean, the regional setting of the transect, existing data, models for volcanic rifted-margin formation, and our main objectives. We also explain the important secondary objectives, with relation to the formation of the Irminger Basin south of the Denmark Strait, between Iceland and Greenland, the overflow history of the Denmark Strait, and the history of glaciation in Greenland. 
A

\begin{tabular}{cccc} 
Zone III | & \multicolumn{2}{c}{ Zone II } & Zone I \\
$\begin{array}{c}\text { 'Normal' } \\
\text { oceanic crust }\end{array}$ & $\begin{array}{c}\text { Main zone of } \\
\text { SDRS }\end{array}$ & $\begin{array}{c}\text { Featheredge } \\
\text { of SDRS } \\
\text { Outer high }\end{array}$ & $\begin{array}{c}\text { Zone of plateau basalts } \\
\text { and sills }\end{array}$ \\
Marginal escarpment
\end{tabular}

Figure 1. Schematic diagrams illustrating the general structure of volcanic rifted margins. Three zones can be distinguished: an inner zone with dikes, sills, and plateau basalts; a central zone of a seaward-dipping reflector sequences (SDRS); and an outer zone of "normal" oceanic crust. Margin structure may vary according to lithospheric setting. A. In this example, breakup takes place within an older continental rift zone that is partly reactivated and intruded by sills. This type of margin is typified by the Vøring Plateau (Eldholm, Thiede, Taylor, et al., 1987). B. A volcanic rifted margin developed in a cratonic area, such as the Southeast Greenland Margin. The basement has been strongly deformed flexurally below the featheredge of the SDRS; as in Example A, continental flood basalts may build up in Zone I and on the adjacent land, with sills being restricted to sedimentary basins, should any be present. High-seismic-velocity lower crust, possibly representing underplated igneous crust, is present below the central part of the margin (cf. Holbrook and Keleman, 1993).

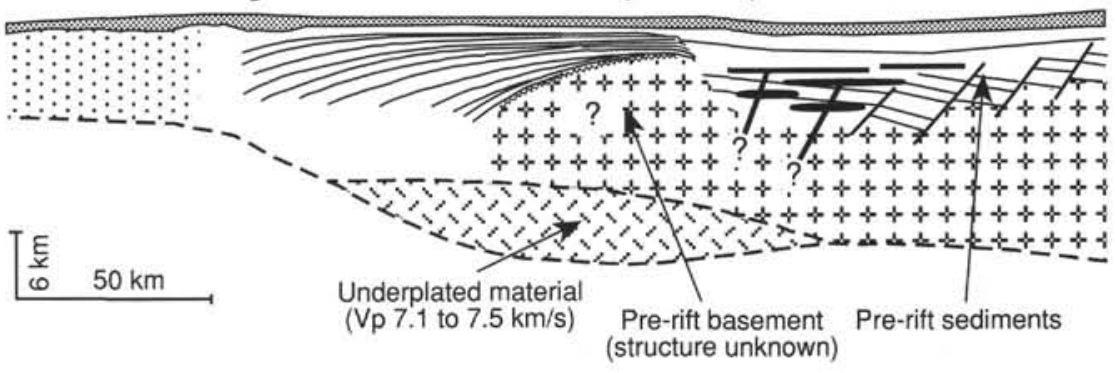

B

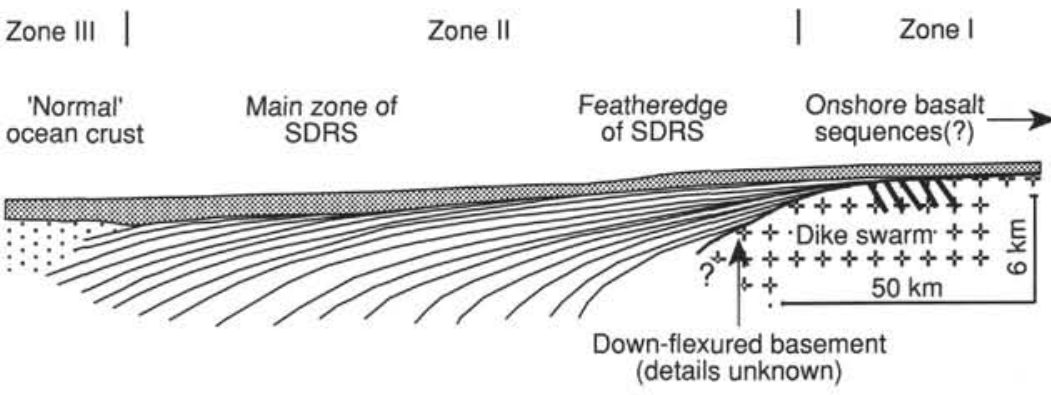

\section{PHYSIOGRAPHY AND DEVELOPMENT OF THE NORTHEAST ATLANTIC}

In this chapter, we define the Northeast Atlantic as the ocean basin that developed between the (now extinct) triple junction south of Greenland and the Spitsbergen-Barents Sea margin in the north (Figs. 2 and 3). The following review of the area is of a general nature and is intended to provide a framework for the initial reporting of Leg 152 objectives and results.

The physiography of the approximately $55-\mathrm{m} . \mathrm{y}$-old Northeast Atlantic Basin strongly reflects the presence of several spreading centers, the Iceland hotspot, and the locally complex plate kinematic development of the area. The complete system is divided into a number of ocean basins that are separated by distinct ridges and plateaus (Fig. 2 ). The presently active plate boundary is manifested successively from south to north as the Reykjanes Ridge, the Neovolcanic Zone of Iceland, the Kolbeinsey Ridge, the Mohns Ridge, and the Knipovich Ridge (Fig. 2; Talwani and Eldholm, 1977; Eldholm et al., 1990). Complex or anomalous spreading has been found in two places: highly oblique spreading occurs along the Knipovich Ridge (Crane et al., 1991 ) and in southern Iceland, where two overlapping volcanic systems are present (Bott et al., 1983; Einarsson, 1991).

Compared with other parts of the ocean basins, the Northeast Atlantic is, in part, unusually shallow, with the Mid-Atlantic Ridge (MAR) shallowing progressively toward Iceland. Besides being part of the Mid-Atlantic Ridge, Iceland also resides on a transverse ridge, the aseismic Faeroe-Iceland-Greenland Ridge. This ridge is the most striking physiographic feature in the region and is important on a global scale in terms of its oceanographic effect on deep-water flow from the Arctic Ocean into the Atlantic Ocean and beyond. The active Jan Mayen Fracture Zone and the formerly active Greenland and Senja fracture zones have caused other important transverse ridges to form (Fig. 2).

A major shallow plateau, the Iceland Plateau, is present north of Iceland and is bound to the east by the Jan Mayen Ridge. The emergent, volcanically active Jan Mayen Island sits at the intersection of the Jan Mayen Ridge and the Jan Mayen Fracture Zone. An extinct part of the Mid-Atlantic Ridge system forms another distinct ridge (the Aegir Ridge) in the Norway Basin, east of the Jan Mayen Ridge.

Marginal plateaus occur in two places. The Vøring Plateau abuts the mid-Norwegian margin. The outer part of the Vøring Plateau is, in part, of oceanic origin (Talwani et al., 1976; Eldholm, Thiede, Taylor, et al., 1987, 1989). Its anomalous elevation is not fully understood, but may be related to the local presence of an extinct axis of magnetic Chron C24 age (Eldholm, Thiede, Taylor, et al., 1989). The inner Vøring Plateau is of continental origin. The other marginal plateau, the Rockall Plateau, also has a continental origin and is conjugate to the Southeast Greenland Margin (Roberts, Schnitker, et al., 1984).

During its embryonic stages, opening of the Atlantic Ocean progressed northward and west of Greenland during Latest Cretaceous to earliest Tertiary time, which led to the initial formation of the Labrador Sea at some time during magnetic Chrons 33 and 31 (Srivastava and Tapscott, 1986). Seafloor spreading was fully established in the Labrador Sea no later than magnetic Chrons C26r to C27n (Chalmers, 1991; Chalmers et al., 1993). A further expansion of the Atlantic, with the start of seafloor spreading east of Greenland no later than magnetic Chron C24r, caused a ridge-ridge-ridge (RRR) triple-junction to form south of Greenland (Srivastava and Tapscott, 1986).

The initial line of breakup within the Northeast Atlantic had a relatively simple geometry. Two sublinear rift segments in the south and north were connected by a slightly winding segment in the middle (Fig. 3). The winding segment developed at the transition from ancient cratonic lithosphere in the south to younger, remobilized terrane in the north. The lithosphere of the northern area had experienced breakup, followed by plate collision during the middle and late Proterozoic and in the early Phanerozoic (Iapetus ocean and Caledonian orogeny). The latter was followed by orogenic collapse and repeated continental rifting during the late Paleozoic and Mesozoic (Ziegler, 1984, 1992; McClay et al., 1986).

The southern and northern linear segments of the original rift are still active plate boundaries (Reykjanes and Mohns Ridge, respectively). Most of the middle winding-rift axis, however, is now the 


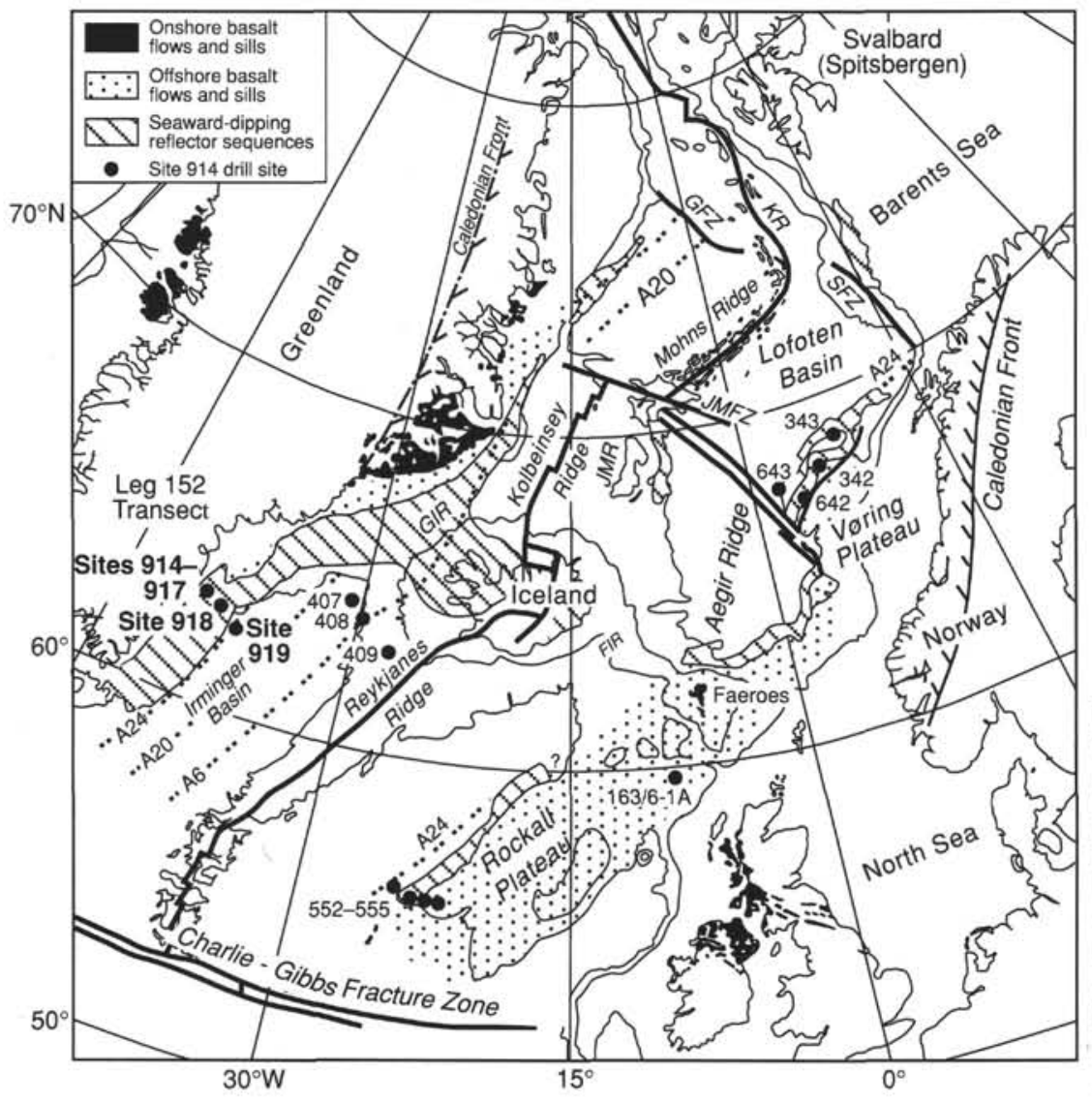

Figure 2. Map of the Northeast Atlantic Ocean showing the main physiographic features of the region, previous DSDP and ODP drill sites, the location of the main SDRS, major early Tertiary basalt outcrop and subcrop, and the broad division into Caledonian and pre-Caledonian crustal blocks (in Greenland and Scandinavia). Abbreviations, from north to south: $\mathrm{KR}=$ Knipovich Ridge; $\mathrm{GFZ}=$ Greenland Fracture Zone; SFZ = Senja Fracture Zone; JMFZ = Jan Mayen Fracture Zone; JMR = Jan Mayen Ridge; GIR = Greenland-Iceland Ridge; FIR = Faeroes-Iceland Ridge. Selected seafloor-spreading magnetic anomalies also are shown. extinct Aegir Ridge, which was replaced during the Neogene by the Kolbeinsey Ridge, possibly through propagation of the MAR northward from the Iceland hotspot (Vogt et al., 1980; Larsen, 1988). A sliver of continental crust was rifted off the East Greenland margin during the formation of the Kolbeinsey Ridge and is now part of the Jan Mayen Ridge (e.g., Eldholm et al., 1990; Larsen, 1990).

Plate separation was approximately orthogonal to the initial line of breakup until late Paleogene time. During this period, the plate boundary between Northeast Greenland and the Spitsbergen-Barents Sea platform was a major dextral transcurrent fault, the Greenland-Senja Fracture Zone. During late Paleogene time, cessation of spreading in the Labrador Sea, as well as other plate reorganizations, led to oblique spreading along the Reykjanes and Mohns ridges and orthogonal spreading along the propagating Kolbeinsey Ridge (Srivastava and Tapscott, 1986; Vogt et al., 1980). At the same time, the transcurrent plate movement along the Greenland-Senja Fracture Zone translated into the present-day, highly oblique Knipovich Ridge, causing separation of the Northeast Greenland and Spitsbergen-Barents Sea platforms (Myhre et al., 1982; Myhre and Eldholm, 1987; Crane et al., 1991; Okay and Crane, 1993).

In summary, the partly shallow seafloor of the Northeast Atlantic results from the thermal effect of the Iceland hotspot. The emergence of Iceland and the shallow nature of the transverse Faeroe-IcelandGreenland Ridge is the result of the local formation of thick igneous crust over the center of the Iceland hotspot. The Iceland Plateau is caused, in part, by young rift propagation. Secondary features, including active and extinct transform faults, detached and isolated fragments of continental crust, and an extinct axis in the Norwegian Basin, also contributed to the physiography of the basin.

Our study centers on the Southeast Greenland continental margin that borders the Irminger Basin southwest of Iceland and south of the Iceland-Greenland Ridge (Fig. 1). The margin and adjacent basin developed in a tectonically relatively simple and uniform way along the western part of the Reykjanes Ridge and is ideally suited for studying the fundamentals of continental breakup.

\section{INITIAL LINE OF BREAKUP AND THE SEAWARD-DIPPING REFLECTOR SEQUENCES}

Present-day mid-ocean ridges are submerged and have an average depth of about $2.7 \mathrm{~km}$ below sea level (Parsons and Sclater, 1977). Except for Iceland, the present-day plate boundary of the Northeast Atlantic also is submerged, although to a considerably shallower depth and with the characteristic north-south symmetric depth profile around the central anomaly in Iceland (Fig. 2). Less-pronounced regional variations in the depth of the mid-ocean ridge frequently occur in other parts of the world ocean. Systematic variations in the chemistry of mid-ocean ridge basalts (including the Northeast Atlantic) suggest that the depth of the ridge axis is controlled by temperature variations in the underlying asthenosphere (Klein and Langmuir, 1987).

The initial accretion of igneous (oceanic) crust along rifted margins generally is thought to take place at a depth close to the mean $2.7 \mathrm{~km}$ of the mid-ocean ridges. Subsidence of continental rift zones to this level, or even deeper, is to be expected, if the preexisting crust has been thinned by a factor of four or more (McKenzie, 1978). Subsequent sinking of the oceanic crust to bathyal depths occurs as the oceanic lithosphere moves away from the spreading ridge and thickens through cooling (Parsons and Sclater, 1977). This may cause further postbreakup subsidence of the adjacent continent/ocean transition and continental margin. It is for these reasons that the Early Cretaceous nonvolcanic continent/ocean transition off Iberia, drilled during Legs 103 and 149 , is now at water depths of 4 to $5 \mathrm{~km}$.

Previous DSDP and ODP drilling (see section below), shore-based studies (e.g., Larsen and Marcussen, 1992), and drilling on the Faeroe Islands (Waagstein, 1988) all suggest near sea-level eruption of the lavas within the SDRS and their continental counterparts. If indeed the 
Figure 3. Map of the North Atlantic region showing the disposition of the major continental blocks at Anomaly 24 time (after Srivastava, 1978). The major outcrops and subcrops of volcanic rocks are shown, together with two postulated locations of the axis of the ancestral Iceland plume: Locations A and B, based on polar wander paths, are after Duncan (1984) and Lawver and Müller (1994), respectively. Location C is the position of the axis based on the distribution of Paleocene and Eocene lavas (White and McKenzie, 1989). Note that north of location $C$, breakup took place within the zone of Caledonian orogeny and late Paleozoic and Mesozoic rifting. South of C, breakup along the Southeast Greenland Margin apparently took place within Precambrian cratonic crust.

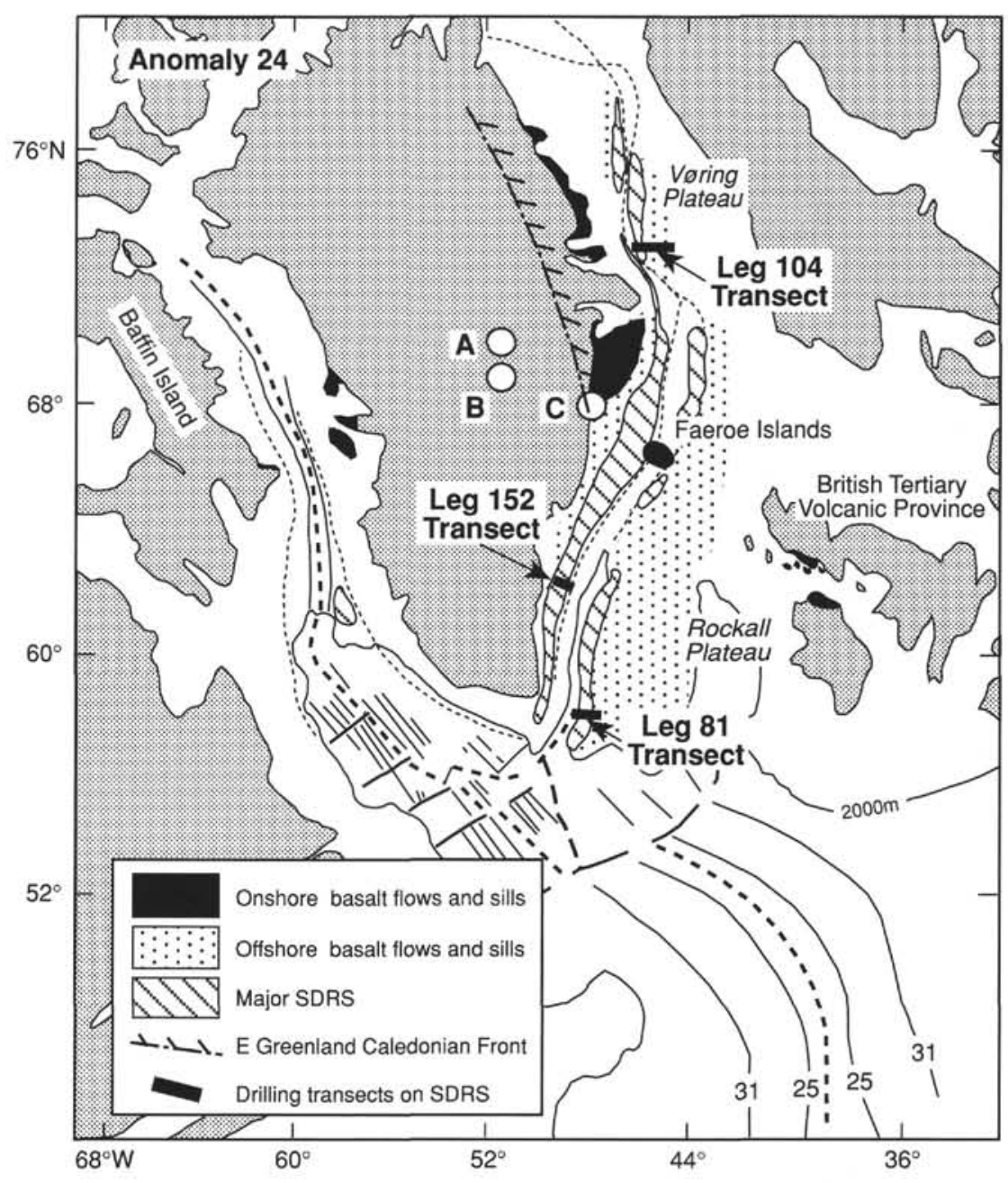

We prefer to explain the origin and structure of SDRS-crust with the kinematic model for crustal accretion in Iceland, which we will refer to as the "Pálmason model" (Pálmason, 1981, 1986). This model implies a downdip source region for the lavas within the SDRS. The present dip and flexure of the lava packages is explained by subsidence in response to differential loading caused by a Gaussian distribution of lava flows around a focused linear rift zone (Fig. 4).

Several investigators noted the general similarity between the SDRS structure and the crustal structure of Iceland (e.g., Mutter et al., 1982; Smythe, 1983; Larsen, 1984; Gibson and Gibbs, 1987). The results of rigorous seismic stratigraphic analysis of the SDRS off East Greenland strongly favor the Pálmason model for their formation (Larsen and Jakobsdottir, 1988). Most notable are the distribution of the SDRS on the margin and toward Iceland (Fig. 2) and the distinct lack of baselap for the SDRS, which locally are more than $6 \mathrm{~km}$ thick. Provisional quantitative modeling of the SDRS along the EG63-transect suggests that they were produced by intense basaltic volcanism that emanated from a 3 - to $10-\mathrm{km}$-wide linear rift zone. Individual eruptions produced lavas that flowed an average of approximately 20 to 25 $\mathrm{km}$ from the central rift zone (Larsen and Jakobsdottir, 1988).

The Pálmason model also implies a rapid transition with depth from lavas to a sheeted dike complex (Fig. 4). The depth of this transition, and hence the thickness of the SDRS, is controlled primarily by the rate of horizontal crustal accretion (i.e., spreading rate), the width of the rift zone, and the rate of volcanic productivity (magma abundance). The portion of the extrusive carapace that will escape later dike injection and be preserved as SDRS increases with increasing spreading rate and with decreasing width of the zone of dike injection (rift zone). Of 
A

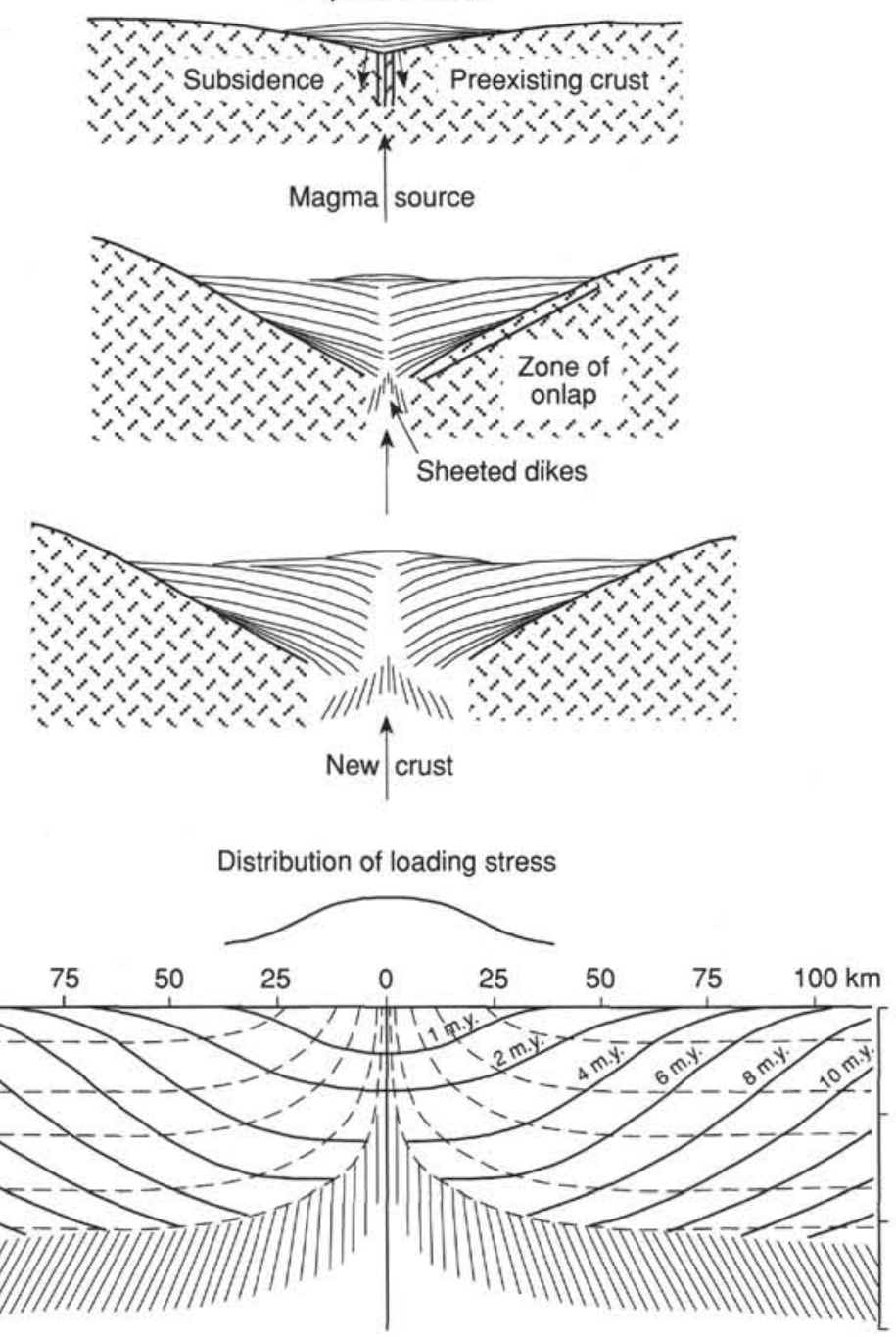

Figure 4. Schematic diagrams showing the formation of seaward-dipping lava sequences. A. Cross section across a volcanic rifted margin, illustrating the flexuring of the margin and the development of onlapping sequences of lavas (after Larsen and Jacobsdóttir, 1988). B. Development of dipping lava sequences in Iceland, after Pálmason (1981). The boundaries between lithological units are shown by continuous sinuous lines of ages ranging from 1 to 10 m.y.; dashed lines show flow paths for individual points. This model is probably generally applicable to SDRS. In both diagrams, sheeted dikes are shown in schematic fashion, oriented normal to flow units; a décollement surface is implied at the base of or below the dike layer. The bulk of the loading stress occurs at the zone of maximum productivity, distributed about the ridge axis. course, this is contingent on sufficiently high magmatic productivity to keep pace with the total amount of extension that took place.

\section{THE SOUTHEAST GREENLAND TRANSECT: PRINCIPAL CHARACTERISTICS}

Transect EG63 is located approximately perpendicular to the East Greenland Margin between $62^{\circ} 40^{\prime}$ and $63^{\circ} 30^{\prime} \mathrm{N}$, approximately 550 $\mathrm{km}$ south of the center of the ancestral Iceland hotspot (Fig. 2). This distance from the plume axis is considered a suitable offset for determining early plume structure. The transect (as planned by the NARMDPG) was to consist of four sites, two of which (EG63-1 and EG63-2) were to be drilled during Leg 152 (Fig. 5).

The EG63 transect is located along the $61^{\circ} \mathrm{N}$ flow line of the oceanic crust (i.e., $61^{\circ} \mathrm{N}$ at the Reykjanes Ridge). This part of the Reykjanes Ridge is just outside the present limit of the isotopic and trace-element signatures from the Icelandic plume (Hart et al., 1973; Schilling, 1973), but is likely to have experienced considerable influence by the plume during breakup (see below). The four proposed sites along the EG63 transect were thought, through systematic stratigraphic sampling of the volcanic development through time along this flow line, to enable us to identify such a possible Iceland plume influence during breakup.

The transect starts on the middle of a narrow shelf, about $50 \mathrm{~km}$ offshore. The inner to mid-shelf is floored by Precambrian basement rocks that have a thin Quaternary cover (Figs. 5 and 6). The outer shelf is floored by the landward feather edge of the southeast Greenland SDRS, covered by up to $1.5 \mathrm{~km}$ of Paleogene and Neogene sediments (see Larsen, 1990, for review of the regional geology). The transect extends seaward across the margin for about $150 \mathrm{~km}$ and terminates in oceanic crust of magnetic Chron C $24 \mathrm{n}$. In age at the seaward edge of the SDRS.

The coverage of magnetic profiles along the drilling transect from the coast and seaward to seafloor-spreading Anomaly $23 \mathrm{n}$ is exceptionally tight (Fig. 7; Larsen and Thorning, 1980). Because of that, and because the SDRS form a flat, nonfaulted, and relatively shallow surface with little sediment cover, it is possible to analyze in more detail the early seafloor-spreading anomalies along this margin than along most other margins.

The magnetic anomaly pattern is simple and well-developed (Fig. 7). The spreading rate from Chrons $\mathrm{C} 24 \mathrm{n} .3 \mathrm{n}$ to $\mathrm{C} 23 \mathrm{n}$. $\mathrm{ln}$ seems to have been unusually high, about $3 \mathrm{~cm} / \mathrm{yr}$, half rate (Larsen, 1980). A similar, or even higher, spreading rate would apply to the pre-C24n.3n interval, if the entire SDRS had been produced during Chron C24r. Except for the feather edge, the SDRS landward of Chron 24n-with the exception of the basalts of the feather-edge region-are associated with a broad magnetic low, which, at least in part, must be of Chron $\mathrm{C} 24 \mathrm{r}$ age. Within this low, anomalies of low amplitude and lying subparallel to the margin and the adjacent Anomaly 24 are present. These can hardly be explained by tectonic or erosional influence of 
A

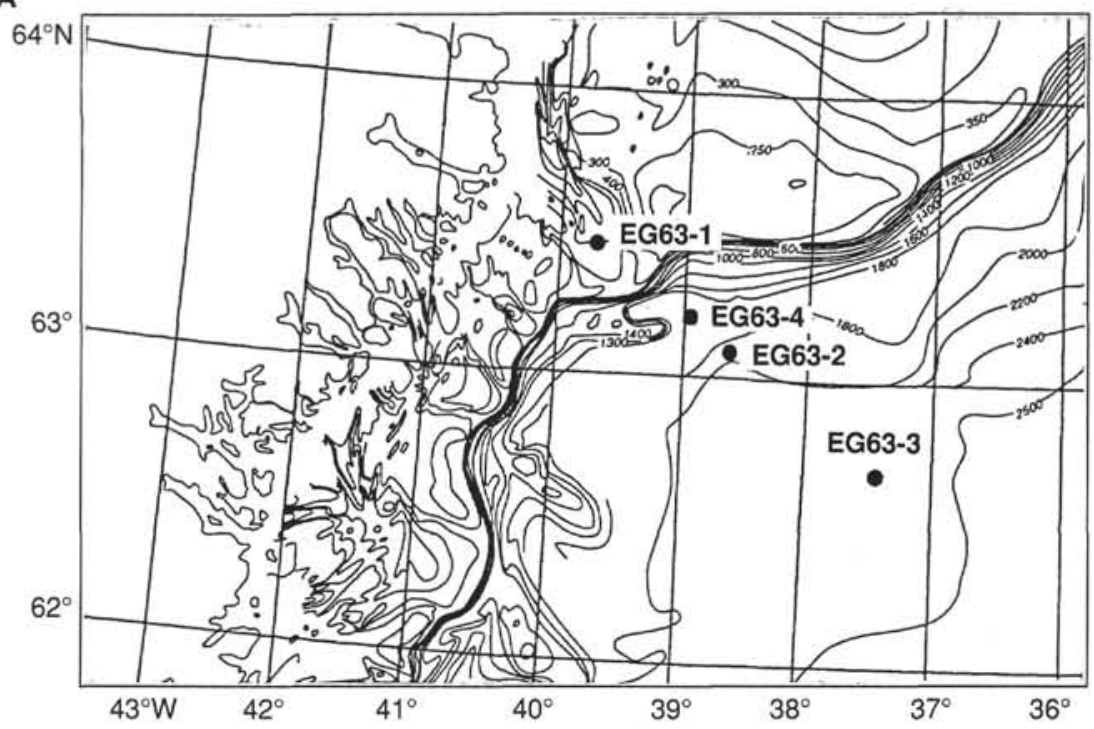

B

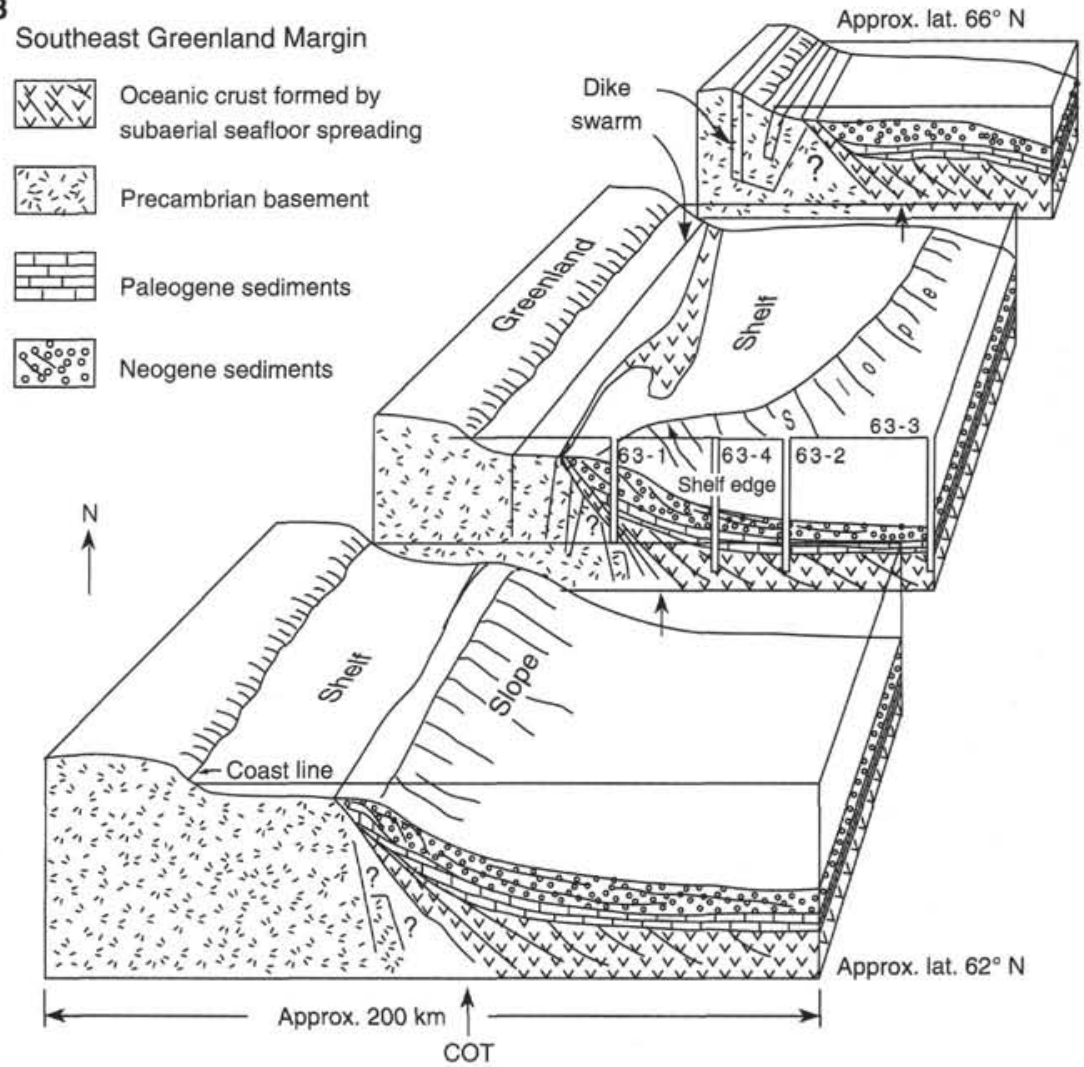

Figure 5. A. Map of the Southeast Greenland Margin showing ocean bathymetry and the location of proposed Leg 152 drill sites. Sites 914 through 917 were drilled at proposed Site EG63-1; Site 918 at EG63-2; and Site 919 at EG63-4. B. Main geological features of the margin. $\mathrm{COT}=$ continent/ocean transition .

$\mathrm{km}$ parallel to the ocean/continent transition, and parallel to the seafloor-spreading anomalies.

In general, the top of the SDRS forms a smooth, nonfaulted surface near the original top of the lava pile. Only along the feather edge of the SDRS can one observe erosion of the SDRS. Local, late volcanic mounds can be identified in some places, but drill sites were planned away from such late volcanic features. Furthermore, the planned drill sites should provide tight constraints on the age and sedimentary facies of the seismically documented facies developments on the shelf, slope, and abyssal plain (Fig. 6). In turn, this will have clear implications for the subsidence history across this margin, 
GGU 81-08 Migrated
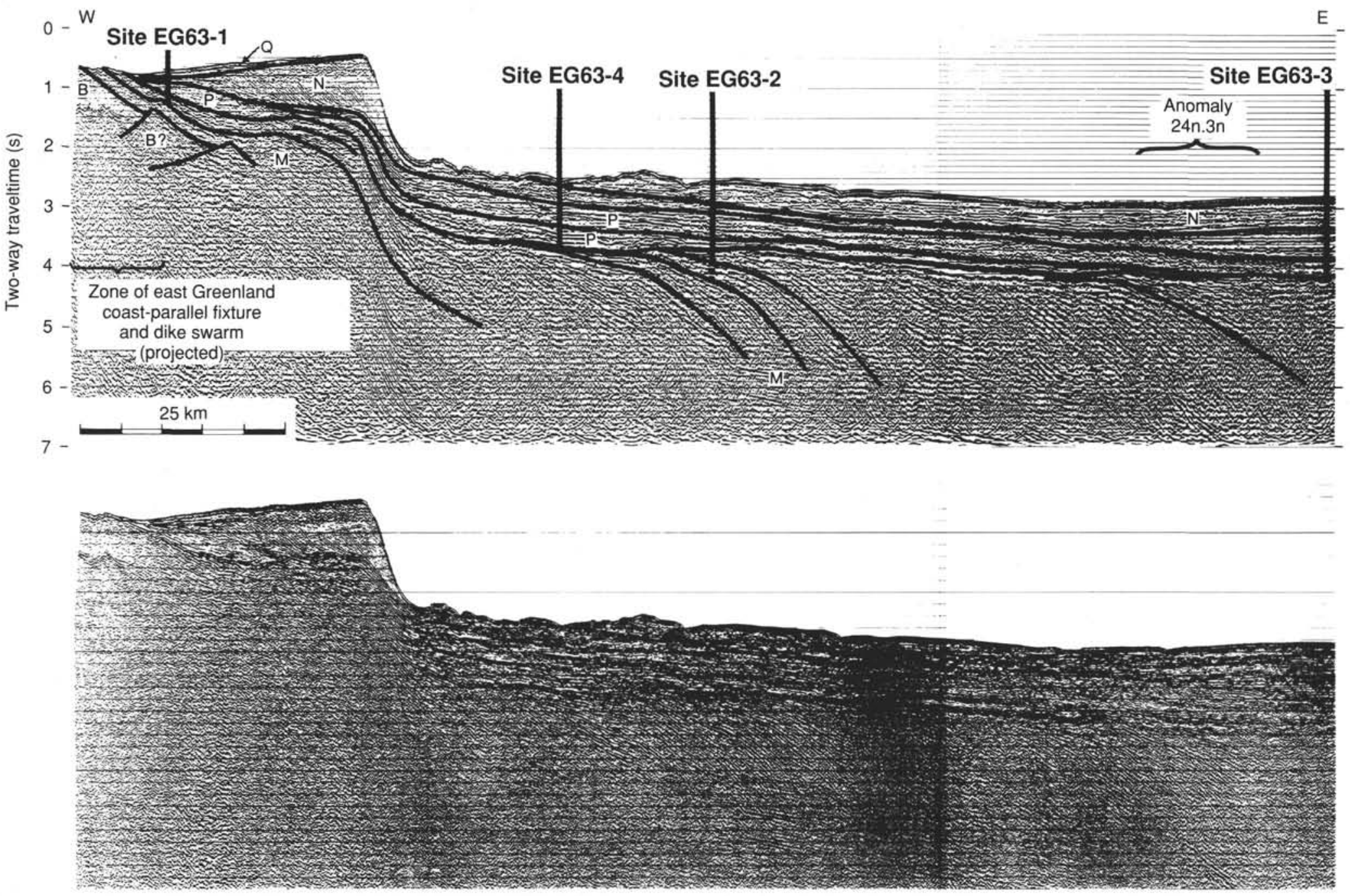

Figure 6. Seismic transect across the Southeast Greenland Margin showing the location of Leg 152 drill sites in relation to the main geological features. Q $=$ Quaternary, N $=$ Neogene, $P=$ Paleocene, $\mathrm{M}=$ SDRS, $\mathrm{B}=$ pre-rift basement. 
Figure 7. Aeromagnetic anomaly data for the Southeast Greenland Margin. From Larsen and Thorning (1980).

the Tertiary uplift of Greenland, the overflow history of the FaeroeIceland-Greenland Ridge, the formation of regional North Atlantic deep-sea unconformities and associated drift deposits, and the history of glaciation at southern Greenland and Iceland (Thiede and Eldholm, 1983; Shackleton et al., 1984; McCave and Tucholke, 1986; Tucholke and Mountain, 1986).

\section{TERTIARY MAGMATISM AND PRINCIPAL RESULTS OF PREVIOUS OCEAN DRILLING OF SDRS IN THE NORTH ATLANTIC}

Next, we present a brief outline of the volcanic history of the North Atlantic Tertiary Volcanic Province (NATVP) and a short review of previous geochemical, petrological, and geochronological investigations of NATVP lavas. The reader is referred to Noe-Nygaard (1974), Upton (1988), and Morton and Parson (1988) for more detailed syntheses.

The early stages of rifting in the North Atlantic region were accompanied by voluminous volcanic activity. Huge outpourings of basalt occurred in the western British Isles, the Faeroe Islands, central East Greenland, West Greenland, Baffin Island, and all along the newly formed European and Greenland continental margins. The volcanic products were deposited in two tectonically and stratigraphically different ways: (1) vertical aggradation of lavas over fully continental crust to form continental flood basalts and (2) the "shingled" aggradation of lavas in transitional or fully igneous oceanic crust that formed the SDRS (Figs. 1, 2, and 3).

The oldest lavas are of early to mid-Paleocene age and are found on the peripheries of the NATVP in West Greenland, Baffin Island, and the British Isles (Fig. 8). However, the bulk of the volcanic activity occurred during late Paleocene and early Eocene time, along the line of eventual separation between Greenland and Europe (Fig. 3). In most regions where good age data are available, magmatic activity, particularly the formation of the basaltic volcanic succession, had a short duration.

The very high rates of melt production recorded in the SDRS and continental flood basalts waned soon after continental breakup along all of the new Mid-Atlantic Ridge, except in the vicinity of Iceland. A ridge of thick crust extends from Greenland through Iceland to the Faeroe Islands (Bott et al., 1983), suggesting that the melting anomaly associated with Iceland has persisted since seafloor spreading began.

Accurate absolute dating of both the oldest and youngest basaltic lavas, especially those in the SDRS, will be required before reliable estimates of eruption rates and eruption duration can be calculated. On the basis of geophysical data, Larsen and Jakobsdóttir (1988) estimated that during breakup, volcanic productivity along the North Atlantic Rift Zone was almost three times higher than that in presentday Iceland. However, sufficiently precise ages are not presently available for the SDRS of the North Atlantic to verify whether these geophysically derived estimates are correct. Drilling of basement during Leg 152 was hoped to lead to recovery of material from different levels within the SDRS for precise ${ }^{40} \mathrm{Ar} /{ }^{39} \mathrm{Ar}$ dating. These, together with magnetostratigraphic and aeromagnetic data, will enable an unparalleled resolution of the timing and duration of magmatism associated with breakup.

Many of the continental volcanic successions in the NATVP contain lavas having enriched trace-element and isotopic signatures. Modeling of isotopic and trace-element data, particularly for lavas from the British Isles and East Greenland, indicates that part of the enriched signature may have been acquired by interaction between the magmas and the continental lithosphere. Both contamination by crustal materials, such as the distinctive Lewisian basement in the British Tertiary Province (e.g., Dickin, 1988; Thompson et al., 1986; Moorbath and Thompson, 1980; Thirlwall and Jones, 1983), and incorporation of components from the subcontinental lithospheric mantle (e.g., Holm, 1988; Gill et al., 1988) appear to have played an important role. The chemical imprint of the continental lithosphere appears to diminish rapidly with time in the SDRS (e.g., Morton and Taylor, 1987; Viereck et al., 1988).

Involvement of several mantle components has also been invoked to account for part of the range in lava compositions observed in the NATVP. Enriched plume mantle, related to the present-day Iceland hotspot, and depleted asthenospheric mantle have been proposed as 


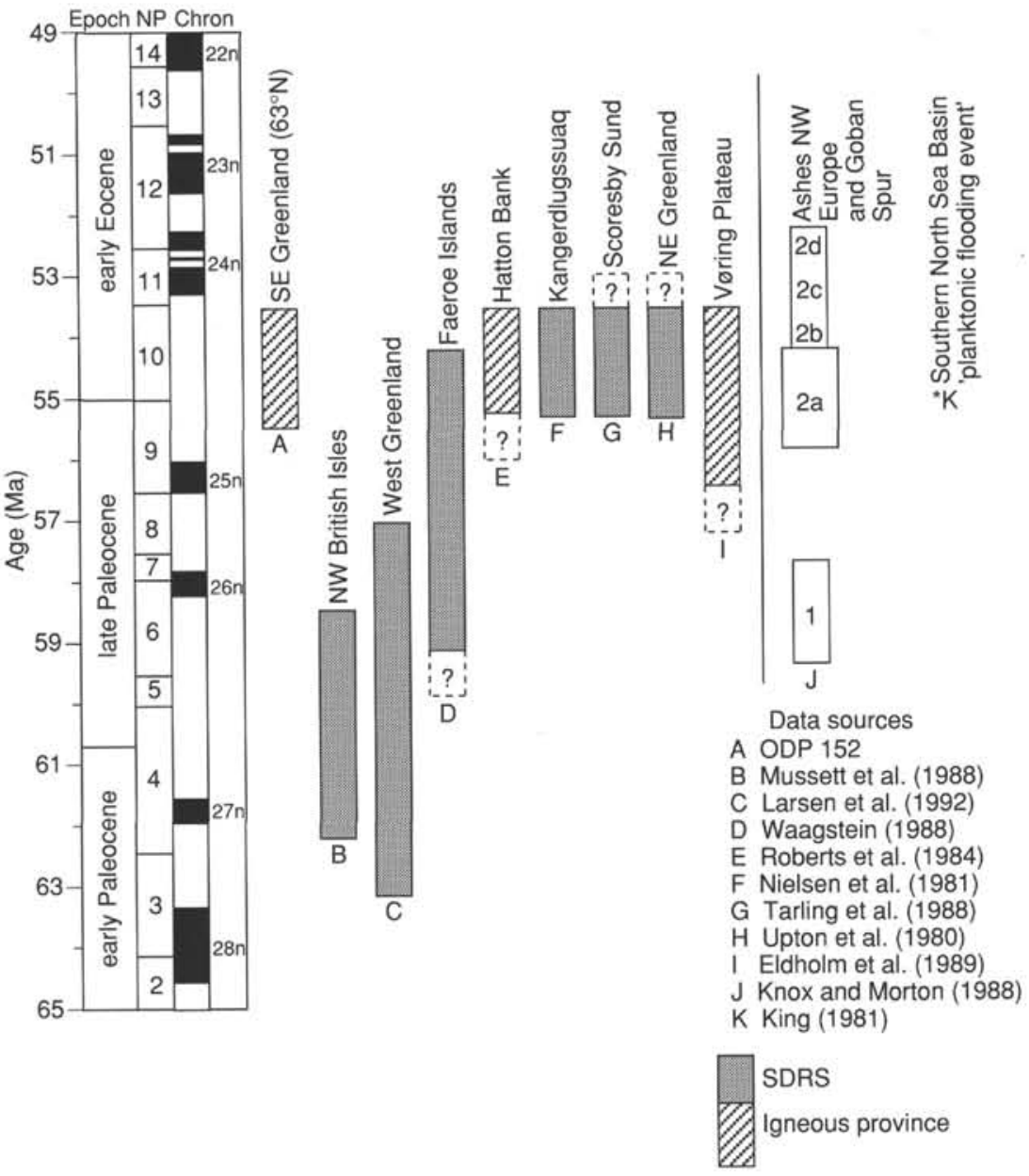

Figure 8 . Age and duration of early Tertiary volcanism in the North Atlantic and West Greenland regions. The relationship between the timing of magmatism and rifting is important, because it may provide constraints on recent models, which link large-scale, widespread magmatism (large igneous provinces: continental flood basalts, SDRS, and oceanic plateaus) to extension and breakup of the lithosphere above a mantle plume (White and McKenzie, 1989). In the North Atlantic Province, the bulk of the basaltic magmatism closely followed the line of breakup, but we still are unsure about the causal link between magmatism and plate separation. For example, did the magmatic event initiate breakup, did the magmatism exploit preexisting thinspots or weaknesses in the lithosphere, or was magmatism a result of lithospheric thinning? Data sources given in the key. Note that no radiometric age determinations were available from Leg 152 samples. Time scale from Cande and Kent (1992). source regions for NATVP lavas (e.g., Brooks and Nielsen, 1982b; Schilling and Noe-Nygaard, 1974; Thirlwall et al., 1994). The relative importance of these mantle components should change as a function of distance from the ancestral Iceland plume axis.

The conditions of mantle melting exert strong control over the compositions of magmas. Modeling suggests that much of the temporal variation in the major- and trace-element compositions of NATVP lavas can be accounted for by changes in the pressure and extent of mantle melting (Fram and Lesher, 1993). Basal lavas in the continental volcanic successions reflect moderately low extents of melting at high mean pressure beneath a thick lithosphere. Lithospheric thinning during eruption of the continental flood basalt and SDRS lavas resulted in a progressive change to higher degrees of melting at lower mean pressures. Modeling of this also supports the presence of a widespread mantle thermal anomaly at the time of continent breakup.

Variations in the depth of fractionation experienced by NATVP lavas also may reflect the structure of the lithosphere. The main series of British Tertiary Volcanic Province lavas experienced fractionation at high pressures (approximately $9 \mathrm{kbar}$ ), which is thought to reflect thickness of the continental crust (Thompson et al., 1982). In the lavas of Scoresby Sund, any high pressure signature is overprinted by low pressure ( $<3.5 \mathrm{kbar}$ ) fractionation (Larsen et al., 1989). An extensive early Tertiary sill complex that developed in the neighboring late Paleozoic to Mesozoic Jameson Land Basin may represent the magma chambers (Larsen and Marcussen, 1992). As explained above, such deep basins are not present along the southern portions of the margin underlain by mainly cratonic basement.

Previous investigations, primarily of the continental portions of the NATVP (reviewed above), provide a framework for examining the evolution of magmatic and mantle processes during development of
North Atlantic volcanic margins. Samples of the SDRS are essential for complete spatial and temporal representation of the early Tertiary burst of volcanism. SDRS have been the target of four previous DSDP and ODP cruises in the North Atlantic: Legs 48 and 81 , on the Rockall Plateau; and Legs 38 and 104, on the Vøring Plateau (Figs. 2 and 3). A summary of the main results of these cruises is included here.

\section{Rockall Plateau/Hatton Bank: DSDP Legs 48 and 81}

The transects drilled on the western flank of the Rockall Plateau are particularly pertinent to Leg 152 because they are approximately conjugate to the EG63 transect (Figs. 2 and 3). Leg 48 failed to reach the SDRS because of technical difficulties (Montadert, Roberts, et al., 1979), but the results of this cruise led Roberts and Montadert (1979) to suggest that the SDRS are generated by progradation during rifting of large-scale foresets of shallow-water and deltaic clastic sediments, interbedded with extrusives. During Leg 81, however, basaltic basement was penetrated at all of its sites (Roberts, Schnitker, et al., 1984). Sites 552 and 553 were located on the main SDRS; Site 555, on the flank of Hatton Bank on the most "landward" or eastern part of the SDRS; and Site 554, on the western boundary of the SDRS. Deep penetration $(>100 \mathrm{~m})$ of the basaltic basement was achieved at Sites 552,553 , and 555 .

Reversely magnetized basalts from the upper part of the SDRS at Site 555 (on the most landward portion of the SDRS) gave a K/Ar age of $53.5 \pm 1.9 \mathrm{Ma}$ (early Eocene: Macintyre and Hamilton, 1984), possibly corresponding to Anomaly $24 \mathrm{r}$. These basalts lie above Zone NP9 (upper Paleocene) sediments, and the K/Ar age is consistent with the biostratigraphic data. The NP9 sediments are predominantly volcanogenic in nature and have been succeeded by sediments that indi- 
cate a brackish, intertidal, lagoonal environment. The basalts at Sites 552 and 554 were erupted in a shallow submarine environment, while those at Site 553 were erupted subaerially.

The basalts recovered from the western Rockall Plateau are tholeiites that exhibit strong depletion of the light rare earth elements (LREE), similar to the Upper Basaltic Series of the Faeroe Islands, or Preshal Mhor basalts from the British Tertiary Volcanic Province (Joron et al., 1984; Merriman et al., 1988). Basalts from Site 553 exhibit low ${ }^{206} \mathrm{~Pb} /{ }^{204} \mathrm{~Pb}$, which is indicative of incorporation of material having low time-integrated $\mathrm{U} / \mathrm{Pb}$, probably from the continental lithosphere (Morton and Taylor, 1987; Merriman et al., 1988).

\section{Vøring Margin: DSDP Leg 38 and ODP Leg 104}

Three sites were drilled seaward of the Vøring Plateau escarpment during Leg 38 (Talwani, Udintsev, et al., 1976). Sites 338 and 342 were drilled on the Outer Vøring Plateau, and Site 343 was drilled at the foot of the plateau in the Lofoten Basin. Short sections of altered basalt were recovered at all three sites; however, the presence of the SDRS was not detected at this time. Shortly after the results of Leg 38 were published, Hinz (1981) recognized the significance of SDRS and proposed that they represent accumulations of basaltic lavas.

A 900-m-thick Eocene volcanic section was drilled on the Vøring Plateau at Hole 642E during Leg 104 (Eldholm, Thiede, Taylor, et al., 1987). The volcanic succession was divided into Upper and Lower Series, separated by about $7 \mathrm{~m}$ of estuarine volcaniclastic rocks. The Upper Series includes tholeiites that are compositionally similar to basalts recovered from segments along the Reykjanes Ridge. The Lower Series includes 13 peraluminous dacite flows that represent melts of crustal metasedimentary rocks. All of the flows were erupted in a subaerial environment (Eldholm, Thiede, Taylor, et al., 1987; Viereck et al., 1988). The Upper Series was erupted during a reversed magnetic polarity interval, tentatively assigned to $24 \mathrm{r}$, which matches the tentatively assigned polarity of the lower parts of the East Greenland basalts on the conjugate margin (Schönharting and Abrahamsen, 1989). The Lower Series contains flows that are normally magnetized (Chron 25n?).

To summarize, the SDRS drilled in the North Atlantic Ocean are late Paleocene or early Eocene in age. Younger SDRS are inferred from seismic records across the Greenland-Iceland-Faeroes Ridge. The Icelandic crust also comprises structures within the lava pile analogous to SDRS (Larsen and Jakobsdottir, 1988). Although predominantly basaltic, a range of compositional types may be present in SDRS. In the lower, earlier parts of the Vøring Plateau SDRS, crustally contaminated basalts recovered from Site 642 show that the magmas were emplaced onto or through continental crust. This is consistent with emplacement of at least the earlier SDRS through the continental crust during breakup (Hinz, 1981; Roberts, Schnitker, et al., 1984). "Uncontaminated" basalts from the Upper Series on the Vøring Plateau are comparable with Holocene basalts from the Reykjanes Ridge that are associated with the Iceland plume. Basalts from the Rockall Plateau have been depleted strongly in LREE, although the lead isotope signature of some of these basalts does indicate contamination of the melts by continental lithosphere (Morton and Taylor, 1987).

\section{INFLUENCE OF THE ICELAND PLUME}

Two fundamentally different types of models have been proposed to account for the excessive magmatic activity along volcanic rifted margins (Fig. 9). In the first model, the necessary thermal energy is supplied from an external source: for example a mantle plume (e.g., Morgan, 1972; Vink, 1984; White and McKenzie 1989; Campbell and Griffiths, 1990). This model is attractive for four reasons: (1) the plume brings in both thermal energy and material to produce the magmas (very large volumes of mantle are required as a melt source); (2) the plume can dynamically uplift the margin, counteracting crustal
A

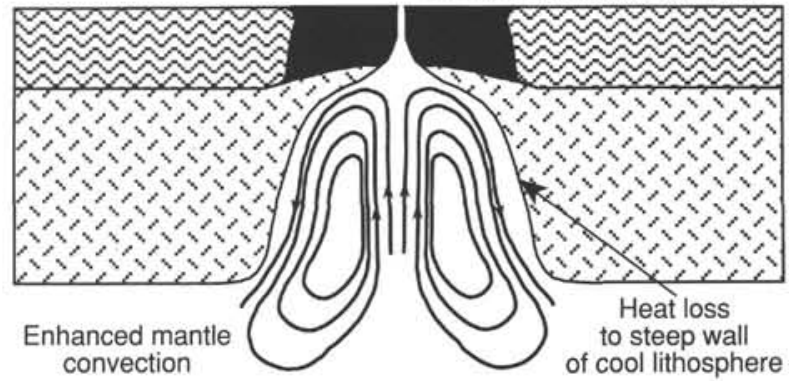

B

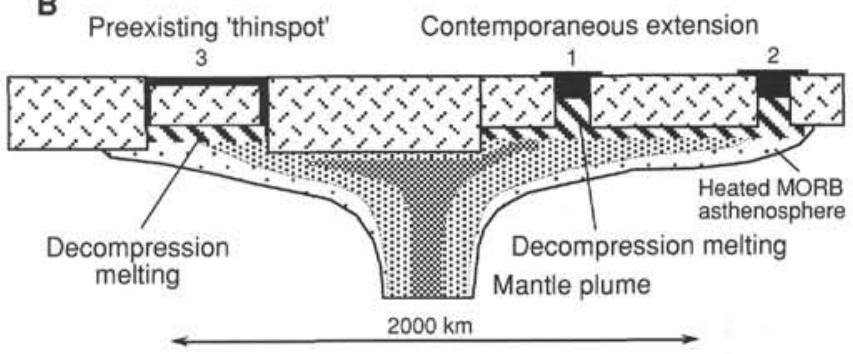

C

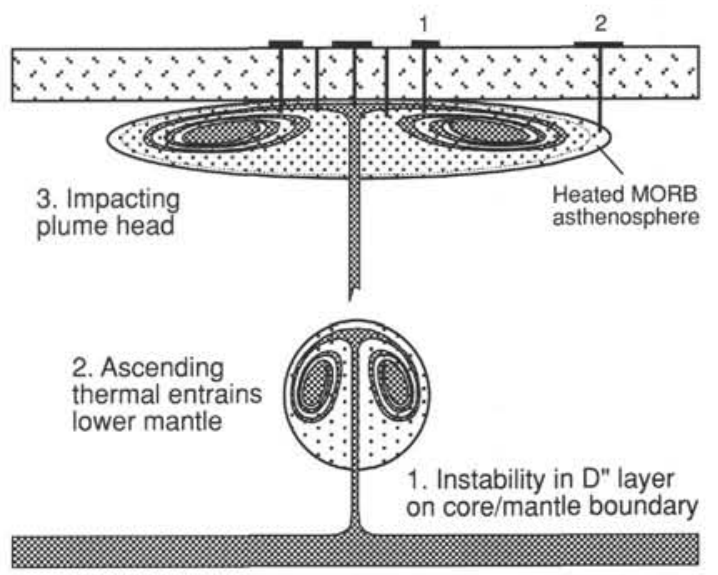

Figure 9. Schematic diagrams (A-C) of possible mechanisms responsible for excessive melt formation at volcanic rifted margins. Note that the scale of $\mathbf{A}$ is far greater than that of $\mathbf{B}$ and C. A. Convective partial melting (Mutter et al., 1988). In this model, a narrow zone of asthenosphere between the flanks of the rifted, steeply walled lithosphere undergoes enhanced convection, caused by the steep thermal gradient between the asthenosphere and the old, cool lithosphere. No external source of heat, such as a mantle plume, is invoked. B. A mantle plume, originating from either the $670-\mathrm{km}$ discontinuity or the lower mantle, incubates beneath the continental lithosphere. The lithosphere has a pronounced topography along its underlying surface. Decompression, allowing melting, occurs when the lithosphere is pulled apart ( 1 and 2) or when the plume mantle or plume-heated mantle ascends into preexisting "highs" or "thinspots" (= young basins at the surface) (3). C. The impacting plume or start-up plume model of Richards et al. (1989) and Campbell and Griffiths (1990). In this model, the plume ascends rapidly from the lower mantle, impacting at the base of the lithosphere. In both plume models, different magma compositions may be generated: $l=$ magma having plumelike isotopic characteristics; 2 = magma having characteristics of the ambient upper mantle, which has only been heated by the plume. The volume of the plume-heated ambient upper mantle may be expected to be much smaller in the case of the plume impact model. 
subsidence induced by extension; (3) the Icelandic plume signature can be detected in some of the Eocene lavas (e.g., Greenland: Thirlwall et al., in press; Vøring Plateau: Viereck et al., 1988); and (4) plate reconstructions show that the plume now beneath Iceland lay beneath central Greenland during late Paleocene to early Eocene time (Fig. 3). The initial burst of volcanic activity may represent the impact at the base of the lithosphere of a large plume head (Richards et al., 1989; Campbell and Griffiths, 1990), or the decompression of a preexisting, largediameter, plume head when the lithosphere above the plume head was thinned as a result of plate divergence (McKenzie and Bickle, 1988; White and McKenzie, 1989; Kent et al., 1992).

The second type of model is that proposed by Mutter et al. (1988). Here, enhanced convection in the asthenosphere during breakup is driven by the strong thermal contrast between the normal-temperature asthenosphere and the cooler, steep rift-flanks of the preexisting continental lithosphere. This model suggests that this process enables enhanced melt generation; the model does not require influx from an external source other than the locally convecting asthenosphere.

Chemical and isotopic studies of basalt samples should help distinguish between these two "end-member" models. Detection of an unequivocal plume signature-based ideally on isotopic ratios because of the possibility of fractionation between trace elements-is required to support the plume hypothesis. However, absence of a plume chemical signature does not necessarily rule out a plume influx; this may mean, for example, that the plume supplied heat to the surrounding mantle or entrained "nonplume" mantle (Fig. 9).

This latter hypothesis is particularly relevant to Leg 152 . The isotopic and trace-element signatures of the Iceland plume have been traced in basalts recovered from the Reykjanes Ridge as far south as about $62^{\circ} \mathrm{N}$ (Hart et al,, 1973; Schilling, 1973) and from the seafloor along a mantle flow line at $63^{\circ} \mathrm{N}$ back to about $35 \mathrm{Ma}$ (Wood et al., 1979). However, on the basis of major-element data, thermal effects can be traced as far south as $50^{\circ} \mathrm{N}$ (Klein and Langmuir, 1987), which is far beyond the limit of the isotopic and trace-element anomalies.

Similarly, the basalts recovered from Hatton Bank during Leg 81 , and erupted distally from the plume center during Eocene time $\left(58^{\circ} \mathrm{N}\right.$ flow line), show no evidence of a plume isotopic signature, although they are clearly part of a major thermal event. The occurrence of depleted MORB-like basalts within the SDRS of the southeast Greenland margin will indicate that it is an important characteristic not restricted to the Hatton Bank/Rockall Plateau region.

Thus, data about the composition of basalts from the North Atlantic may help to constrain the evolution of the Iceland plume. Recently, the hypothesis that plumes may exhibit two types of behavior has been proposed. On the one hand, they may have a steady mantle flux, and a large "head" may incubate, perhaps over several million years, beneath thick lithosphere (Kent, 1991; Kent et al., 1992; Saunders et al., 1992). Little or no surface expression of the plume may be evident, with the possible exception of doming and minor magmatism. Voluminous magmatism occurs when the plume is crossed by thin lithosphere (a "thinspot": Thompson and Gibson, 1991) or when the lithosphere is pulled apart (e.g., White and McKenzie, 1989) (Fig. 9A). On the other hand, voluminous magmatism may represent the arrival of a large plume head at the base of the lithosphere (Fig. 9B) (Campbell and Griffiths, 1990).

A slowly incubating plume would heat the adjacent asthenosphere. This might produce a plume head that has an outer layer of mantle material of higher-than-ambient temperature, but ambient composition (Fig. 9). Essentially, the thermal and compositional components of the plume then are decoupled. An impacting plume would have had far less time to transfer energy to the adjacent mantle, and the thermal and chemical effects would have been much more closely coupled. The transect at $63^{\circ} \mathrm{N}$ on the East Greenland margin should provide another dimension to this picture. Clearly, it will be necessary to fully evaluate the effects of differing depths of melting (Fram and Lesher, 1993) and lithospheric contamination, processes that are likely to have been operative at an evolving rifting margin, before we are able to constrain the evolution of the plume system.

\section{VOLCANICLASTIC DEPOSITS}

Volcaniclastic rocks, whether they are of primary depositional origin (air-fall and ash-flow deposits, hyaloclastites, and breccias) or reworked deposits contain further information about volcanic development with time. Hydroclastic eruptions in a shallow-water environment probably would be associated with deposits of proximal ash, tuff, and lapillistones. Higher in the stratigraphic column, more distally derived tephra from proto-Iceland may reflect the development of silicic magma bodies within the Icelandic volcanic system and may provide important stratigraphic ties to North Atlantic tephra chronology.

\section{SUBSIDENCE ANALYSIS}

Subsidence studies of the southeast Greenland margin and adjacent Irminger Basin can provide important tectonic and paleoceanographic information. Although the drill sites and the SDRS now are located in a variety of depths that range from approximately 500 to $3000 \mathrm{~m}$ (top of SDRS), it is likely that most of the lavas forming the SDRS were erupted under subaerial or shallow submarine conditions close to sea level (cf. Larsen and Jakobsdóttir, 1988). The sediments overlying the SDRS at each site thus should have recorded the transition from a terrestrial to an outer-shelf/slope environment and should provide an estimate of the rate of thermal subsidence of the lithosphere after the formation of the anomalous thick crust. Furthermore, a transect of two or more sites should allow us to trace changes in these factors across the margin and toward the Reykjanes Ridge, presently at a water depth of approximately $2000 \mathrm{~m}$ at the EG63-transect flow line (Fig. 2).

\section{PALEOCEANOGRAPHIC AND PALEOCLIMATIC OBJECTIVES}

The Irminger Basin probably contains records of at least three important paleoceanographic events: (1) the overflow of the FaeroeIceland-Greenland Ridge; (2) the development of North Atlantic drift and contour current deposits; and (3) late Cenozoic climatic deterioration and glaciation.

Few oceanic gateways can compete with the Greenland-Faeroes Ridge in having such a profound influence on today's world hydrography (Bott et al., 1983; Thiede, 1983; Miller et al., 1985). Reconstructions of the subsidence history of the ridge system suggest that its eastern parts sank beneath sea level sometime during the middle Eocene, while in the Denmark Strait area (between Iceland and Greenland), the ridge sank during early to middle Miocene time (Thiede and Eldholm, 1983). However, the distribution of shallow-water benthic foraminifers indicates that the Nordic seas were effectively isolated from any "deep" Atlantic influence until middle Miocene time (Berggren and Schnitker, 1983; Thiede, 1983).

Overflows have influenced the Atlantic and global deep-water masses through their contribution both to the production of North Atlantic Deep Water and to the formation of associated sedimentary rocks. Results from Leg 152 complement those from Leg 151 from the main source regions of deep Arctic water, north of the GreenlandScotland Ridge (Myhre, Thiede, Firth, et al., in press) by possibly providing data about the overflow history of this water mass across the Iceland-Greenland Ridge, through the Denmark Strait and into the Irminger Basin.

Extensive and thick drift deposits are known to occur in the Irminger Basin, but these have received little attention. The most well-studied area is the Eirik Ridge south of Greenland (Miller and Tucholke, 1983; McCave and Tucholke, 1986; Tucholke and Mountain, 1986). However, sediment waves that may represent drift deposits occur within the deep parts of the Irminger Basin, toward the East 
Greenland margin (Larsen, 1993). Drilling and logging results will aid with detailed seismic stratigraphic interpretation of these structures and will provide control on the age and physical and chemical properties of the deep-water mass associated with the accumulation of these deposits. A considerable influx of glaciogenic material from the East Greenland margin into the sediments is expected to be present, and systematic variations should be visible in the logging data, in particular in the porosity, gamma-ray, velocity, and microresistivity data, all of which are sensitive to sedimentological parameters, such as grain size, mineral type, and abundance. The Norwegian-Greenland seas and the Arctic Ocean are surrounded by landmasses that acted as foci for the late Cenozoic Northern Hemisphere ice sheets. The history of large glaciations in the high northern latitudes has been firmly documented only back to approximately $2.5 \mathrm{Ma}$, although glaciation in some areas must have started earlier during the Neogene (Shackleton et al., 1984; Ruddiman and Raymo, 1988; Jansen et al., 1988). However, the older glaciation history of the western part of the North Atlantic (including Greenland) is not well documented.

The Greenland continent spans more than $20^{\circ}$ in latitude from the subarctic in the south to the high Arctic Ocean in the north. During periods of climatic cooling and subsequent glaciation, strong climatic gradients are supposed to have existed in southern Greenland. With the high elevation (1500-2000 m) of the interior of southern Greenland, this area may have experienced some of the first glaciations within the lower high latitudes. Indeed, despite its relatively southern latitude, the southeast Greenland coast presently is heavily glaciated.

Transect EG63 is centrally positioned for monitoring the development of the south Greenland Ice Sheet. Planned sites are positioned in the center of a major fjord-shelf-trough-fan system (Fig. 5). Bathymetry indicates that during glacial times, surging ice streams from the major fjords between $63^{\circ}$ and $66^{\circ} \mathrm{N}$ in mainland Greenland, at least in part, moved across the shelf within this fjord-trough-fan system. The more seaward proposed Site EG63-2 is located distally to this system and has recorded the deep-sea sedimentary response to climatic changes and the glacial processes on the shelf, including dropstone sedimentation.

\section{CHRONOSTRATIGRAPHIC STUDIES}

All of the internationally recognized Paleogene stages were originally defined in sections exposed adjacent to the North Sea Basin (Hardenbol and Berggren, 1979; Berggren, Flynn, and Kent, 1985; Jenkins and Luterbacher, 1992). However, many, if not all, of the Paleogene epoch boundaries probably will be redefined in more complete, deep-marine sections outside of the North Sea Basin area. High-resolution chronostratigraphic studies of the middle and upper
Paleogene marine sequences adjacent to the North Sea Basin provide an excellent opportunity for identifying markers and events in which to correlate the bases of a number of northwest European stages with the global marine record. The Tertiary marine sediments recovered during Leg 152 are important with regard to such a new chronostratigraphic framework.

Finally, the detailed magnetobiostratigraphic correlations resulting from drilling at high northerly latitudes may provide the first magnetostratigraphic calibrations for a number of Cenozoic bioevents in the northern high latitudes and should facilitate correlations from low to high latitudes.

\section{SUMMARY OF THE PRINCIPAL SCIENTIFIC OBJECTIVES OF LEG 152}

1. To determine the environment of emplacement of the SDRS: subaerial, shallow water, or marine.

2. To determine the age and rate of accretion of the SDRS on the southeast Greenland margin and to assess the duration of the thermal pulse along this part of the North Atlantic margin, using absolute radiometric age determinations, biostratigraphy, paleomagnetism, and seafloor-spreading isochrons.

3. To determine the composition of the basalts and to evaluate mantle melting processes, the role of short-, as opposed to long-lived magma chambers, the effects of crustal contamination, and the influence of the Iceland plume.

4. To evaluate models of plume origin and evolution through studies of margin structure, uplift, and basalt composition.

5. To study the subsidence and erosional histories of the volcanic margin through heat-flow studies, sedimentology, biostratigraphy, and paleoecology.

6. To investigate the Cenozoic evolution of the Iceland plume activity by study of recovered tephra samples and to contribute to the North Atlantic tephrachronology.

7. To investigate the oceanographic history of the Irminger Basin, with particular reference to the onset of overspill across the GreenlandIceland Ridge and the influx of glacial debris from the Greenland margin.

8. To establish detailed correlation between Cenozoic bioevents and magnetostratigraphic events in the northern high latitudes.

9. To investigate the glaciomarine processes and history of the southeast Greenland margin.

\section{Ms 152IR-101}

